\title{
Peran Lingkungan Madrasah Dalam Pembentukan Karakter Siswa MIM 2 Slinga Kaligondang Purbalingga
}

\author{
Laela Mukharoh ${ }^{1}$, Tutuk Ningsih ${ }^{2}$ \\ ${ }^{1,2}$ UIN Prof. KH. Saifuddin Zuhri
}

\begin{tabular}{|c|c|}
\hline Article Info & Abstract \\
\hline $\begin{array}{l}\text { Article history: } \\
\text { Received } 23 \text { November } 2021 \\
\text { Publish } 01 \text { Januari } 2022\end{array}$ & $\begin{array}{l}\text { The study, entitled the role of the madrasah environment in the character building of } \\
\text { students at MI Muhammadiyah } 2 \text { Slinga kaligondang purbalingga has the aim of } \\
\text { providing an overview of how the role of the madrasah environment can shape the } \\
\text { character of MI Muhammadiyah } 2 \text { Slinga students. This paper is a deductive paper, } \\
\text { the result of research with environmental research subjects at MI Muhammadiyah } 2 \\
\text { Slinga }\end{array}$ \\
\hline $\begin{array}{l}\text { Keywords: } \\
\text { The Role Of The Madrasc } \\
\text { Environment. }\end{array}$ & $\begin{array}{l}\text { Slinga could be shaped by the interaction between students and stakeholders in the } \\
\text { madrasah environment and the situation in the madrasah environment. }\end{array}$ \\
\hline
\end{tabular}

The Formation Of Student

Character

\section{InfoArtikel}

Article history:

Diterima 23 November 2021

Publis 01 Januari 2022
Corresponding Author:

Laela Mukharoh

UIN Prof. KH. Saifuddin Zuhri

Email: laela.mim2slinga@gmail.com

\section{PENDAHULUAN}

Pendidikan di Indonesia sekarang ini sedang mengalami berbagai kendala, seperti: kurangnya pemerataan guru di daerah terpencil, perubahan kurikulum yang mengakibatkan peserta didik bingung belajar dalam menghadapi ujian nasional. Tidak hanya itu, kemajuan teknologi juga membawa dampak positif dan negatif terhadap peserta didik. Dampak positif yang ditimbulkan peserta didik dapat mengakses ilmu pengetahuan memalui jaringan internet, namun apabila peserta didik salah menggunakan internet tersebut akan mengakibatkan dampak negatif seperti ketagihan bermain game. Persoalan lain pun muncul seiring dengan perkembangan zaman. Banyak orang tua peserta didik mengeluhkan adanya perbedaan antara peserta didik zaman sekarang dengan zaman dahulu. Apabila di zaman dahulu peserta didik memiliki sopan santun atau unggah-ungguh dalam pergaulan sehari-hari. Mereka masih bisa berbahasa Jawa Krama sebagai alat komunikasi dengan orang tua atau orang yang patut untuk dihormati. Selain itu mereka peka terhadap orang lain yang membutuhkan bantuan. Jika dibandingkan dengan peserta didik sekarang, rasa-rasanya tatakrama dan unggah-ungguh basa dirasakan mulai luntur, misalnya saja peserta didik sekarang kurang bisa 
menguasai basa Jawa Krama sebagai alat komunikasi sehingga mereka dianggap tidak menghormati orang tua. Hal ini disebabkan berbagai faktor, mulai dari pengaruh televisi dan kemajuan teknologi.

Dari berbagai kendala itulah akhirnya pemerintah melalui dinas Pendidikan menerapkan kurikulum berbasis karakter disetiap mata pelajaran. Pendidikan karakter ini diharapkan mampu membentuk pribadi peserta didik menjadi lebih berkepribadian sehingga di masa yang akan datang mereka menjadi manusia yang dapat diandalkan demi kemajuan Bangsa Indonesia.

Berdasarkan latar belakang masalah tersebut, maka dapat dipaparkan rumusan masalah yaitu dapatkah lingkungan Madrasah menjadi media pembelajaran karakter di madrasah? . Sedangkan tujuan dari penulisan artikel ini adalah untuk mengetahui bagaimana lingkungan madrasah dapat dijadikan media dalam pembelajaran pendidikan karakter. Artikel ini memberikan manfaat kepada para pembaca khususnya untuk para pendidik Semoga makalah ini mampu menjadi inspirasi dalam pembelajaran di Madrasah, serta memberikan tuntunan untuk keberhasilan penanaman karakter di Madrasah.

\section{METODE PENELITIAN}

Penelitian ini merupakan penelitian lapangan dengan metode observasi. Teknik penggumpulan data pada penelitian ini menggunakan teknik wawancara, observasi dandokumentasi, Analisis pada penelitian ini menggunakan metode deskriptif kualitatif', yaitu mendeskripsikan data-data yang terkumpulkan. Obyek dalam penelitian ini adalah nilai nilai karakter peserta didik. Subyek penelitian atau responden sebagai informan, yang dipilih sebagai subyek pertama yaitu guru dan lingkungan sekitar madrasah.

\section{HASIL PENELITIAN DAN PEMBAHASAN}

\subsection{Indikator Keberhasilan Program Pendidikan Karakter}

Menurut Hasan dkk, ada dua jenis indikator yang dikembangkan dalam program pendidikan karakter. Pertama, indikator untuk madrasah dan kelas. Kedua, indikator untuk mata pelajaran. Indikator madrasah dan kelas adalah penanda yang digunakan oleh kepala madrasah, guru, dan personalia madrasah dalam merencanakan, melaksanakan, dan mengevaluasi madrasah sebagai lembaga pelaksana pendidikan budaya dan karakter bangsa. Indikator ini berkenaan juga dengan kegiatan madrasah yang diprogramkan dan kegiatan madrasah seharihari. Indikator mata pelajaran menggambarkan perilaku efektif seorang peserta didik berkenaan dengan mata pelajaran tertentu.

Ada 18 nilai yang harus dikembangkan madrasah dalam menentukan keberhasilan pendidikan karakter, yaitu: (1) religius, (2) jujur, (3) toleransi, (4) disiplin, (5) kerja keras, (6) kreatif, (7) mandiri, (8) demokratis, (9) rasa ingin tahu, (10) semangat kebangsaan, (11) cinta tanah ait, (12) menghargai prestasi, (13) bersahabat/komunikatif, (14) cinta damai, (15) gemar membaca, (16) peduli lingkungan, (17) peduli sosial, (18) tanggungjawab. Adapun indikator keberhasilannya dapat dikembangkan sebagaimana dicontohkan pada tabel berikut:

\begin{tabular}{|l|c|l|}
\hline No. & Nilai & \multicolumn{1}{c|}{ Indikator } \\
\hline 1. & Religius & $>$ Mengucapkan salam. \\
& & $>$ Berdoa sebelum dan sesudah belajar. \\
& & $>$ Melaksanakan ibadah keagamaan. \\
& & $>$ Merayakan hari besar keagamaan. \\
\hline 2. & Jujur & $>$ Membuat dan mengerjakan tugas secara benar. \\
& & $>$ Tidak menyontek atau memberi contekan. \\
& $>$ Membangun koperasi atau kantin kejujuran. \\
& & $>$ Melaporkan kegiatan madrasah secara transparan. \\
\hline
\end{tabular}




\begin{tabular}{|c|c|c|}
\hline & & $\begin{array}{l}\text { Melakukan sistem perekrutan peserta didik secara } \\
\text { benar dan adil. } \\
\text { Melakukan sistem penilaian yang akuntabel dan } \\
\text { tidak melakukan manipulasi. }\end{array}$ \\
\hline 3. & Toleransi & $\begin{array}{l}\text { Memperlakukan orang lain dengan cara yang sama } \\
\text { dan tidak membeda-bedakan agama, suku, ras, dan } \\
\text { golongan. } \\
\text { Menghargai perbedaan yang ada tanpa melecehkan } \\
\text { kelompok yang lain. }\end{array}$ \\
\hline 4. & Disiplin & $\begin{array}{l}\text { Guru dan peserta didik hadir tepat waktu. } \\
\text { Menegakan prinsip dengan memberikan } \\
\text { punishment bagi yang melanggar dan reward bagi } \\
\text { yang berprestasi. } \\
>\text { Menjalankan tatatertib madrasah. }\end{array}$ \\
\hline 5. & Kerja keras & $\begin{array}{l}>\text { Pengelolaan pembelajaran yang menantang. } \\
>\text { Mendorong semua warga madrasah untuk } \\
\text { berprestasi. } \\
>\text { Berkompetisi secara fair. } \\
>\text { Memberikan penghargaan kepada peserta didik } \\
\text { berprestasi. }\end{array}$ \\
\hline 6. & Kreatif & $\begin{array}{l}\text { Menciptakan ide-ide baru di madrasah. } \\
\text { Menghargai setiap karya yang unik dan berbeda. } \\
\text { Membangun suasana belajar yang mendorong } \\
\text { munculnya kreatifitas peserta didik. }\end{array}$ \\
\hline 7. & Mandiri & $\begin{array}{l}\text { Melatih peserta didik agar mampu bekerja secara } \\
\text { mandiri. } \\
>\text { Membangun kemandirian peserta didik melalui } \\
\text { tugas-tugas yang bersifat individu. }\end{array}$ \\
\hline 8. & Demokratis & $\begin{array}{l}\text { Tidak memaksakan kehendak kepada orang lain. } \\
\text { Sistem pemilihan ketua kelas daan pengurus kelas } \\
\text { secara demokratis. } \\
\text { Mendasarkan setiap keputusan pada musyawarah } \\
\text { mufakat. }\end{array}$ \\
\hline 9. & $\begin{array}{c}\text { Rasa ingin } \\
\text { tahu }\end{array}$ & $\begin{array}{l}\text { Sistem pembelajaran diarahkan untuk } \\
\text { mengeksplorasi keingintahuan peserta didik. } \\
\text { Madrasah memberikan fasilitas, baik melalui media } \\
\text { cetak maupun elektronik, agar peserta didik dapat } \\
\text { mencari informasi yang baru. }\end{array}$ \\
\hline 10. & $\begin{array}{l}\text { Semangat } \\
\text { kebangsaan }\end{array}$ & $\begin{array}{l}\text { Memperingati hari-hari besar nasional. } \\
>\text { Meneladani para pahlawan nasional. } \\
>\text { Berkunjung ke tempat-tempat bersejarah. } \\
>\text { Melaksanakan upacara rutin madrasah. } \\
>\text { Mengikutsertakan dalam kegiatan-kegiatan } \\
\text { kebangsaan. } \\
>\text { Memajang gambar tokoh-tokoh bangsa. }\end{array}$ \\
\hline 11. & $\begin{array}{c}\text { Cinta tanah } \\
\text { air }\end{array}$ & $\begin{array}{l}\text { Menanamkan nasionalisme dan rasa persatuan dan } \\
\text { kesatuan bangsa. } \\
>\text { Menggunakan bahasa Indonesia dengan baik dan }\end{array}$ \\
\hline
\end{tabular}




\begin{tabular}{|c|c|c|}
\hline & & $\begin{aligned} & \text { benar. } \\
& \text { Memajang bendera Indonesia, Pancasila, gambar } \\
& \text { presiden serta simbol-simbol negara lainnya. } \\
& \text { Bangga dengan karya bangsa. } \\
& \text { Melestarikan seni dan budaya bangsa. }\end{aligned}$ \\
\hline 12. & $\begin{array}{l}\text { Menghargai } \\
\text { prestasi }\end{array}$ & $\begin{array}{l}\text { Mengabadikan dan memajang hasil karya peserta } \\
\text { didik di madrasah. } \\
>\text { Memberikan reward setiap warga madrasah yang } \\
\text { berprestasi. } \\
>\text { Melatih dan membina generasi penerus untuk } \\
\text { mencontoh hasil atau prestasi generasi sebelumnya. }\end{array}$ \\
\hline 13. & $\begin{array}{l}\text { Bersahabat/ } \\
\text { Komunikatif. }\end{array}$ & $\begin{array}{l}>\text { Saling menghargai dan menghormati. } \\
\text { Guru menyayangi peserta didik dan peserta didik } \\
\text { menghormati guru. } \\
>\text { Tidak menjaga jarak. } \\
>\text { Tidak membeda-bedakan dalam berkomunikasi. }\end{array}$ \\
\hline 14. & Cinta damai & $\begin{array}{l}\text { Menciptakan suasana kelas yang tenteram. } \\
\text { Tidak menoleransi segala bentuk tindakan } \\
\text { kekerasan. } \\
>\text { Mendorong terciptanya harmonisasi kelas dan } \\
\text { madrasah. }\end{array}$ \\
\hline 15. & $\begin{array}{l}\text { Gemar } \\
\text { membaca }\end{array}$ & $\begin{array}{l}\text { Mendorong dan memfasilitasi peserta didik untuk } \\
\text { gemar membaca. } \\
>\text { Setiap pembelajaran didukung dengan sumber } \\
\text { bacaan atau referensi. } \\
>\text { Adanya ruang baca, baik di perpustakaan maupun } \\
\text { ruang khusus tertentu. } \\
>\text { Menyediakan buku-buku sesuai dengan tahap } \\
\text { perkembangan peserta didik. } \\
>\text { Menyediakan buku-buku yang dapat menarik minat } \\
\text { baca peserta didik. }\end{array}$ \\
\hline 16. & $\begin{array}{l}\text { Peduli } \\
\text { lingkungan }\end{array}$ & $\begin{array}{l}\text { Menjaga lingkungan kelas dan madrasah. } \\
\text { Memelihara tumbuh-tumbuhan dengan baik tanpa } \\
\text { menginjak atau merusaknya. } \\
>\text { Mendukung program go green (penghijauan) di } \\
\text { lingkungan madrasah. } \\
>\text { Tersedianya tempat untuk membuang sampah } \\
\text { organik dan sampah nonorganik. } \\
>\text { Menyediakan kamar mandi, air bersih, dan tempat } \\
\text { cucui tangan. }\end{array}$ \\
\hline 17. & Peduli sosial & $\begin{array}{l}\text { Madrasah memberikan bantuan kepada peserta } \\
\text { didik yang kurang mampu. } \\
>\text { Melakukan kegiatan bakti sosial. } \\
>\text { Melakukan kunjungan di daerah atau kawasan } \\
\text { marginal. } \\
>\text { Menyediakan kotak amal atau sumbangan. }\end{array}$ \\
\hline 18. & $\begin{array}{l}\text { Tanggung } \\
\text { Jawab }\end{array}$ & $\begin{array}{l}\text { Mengerjakan tugas dan pekerjaan rumah dengan } \\
\text { baik. }\end{array}$ \\
\hline
\end{tabular}




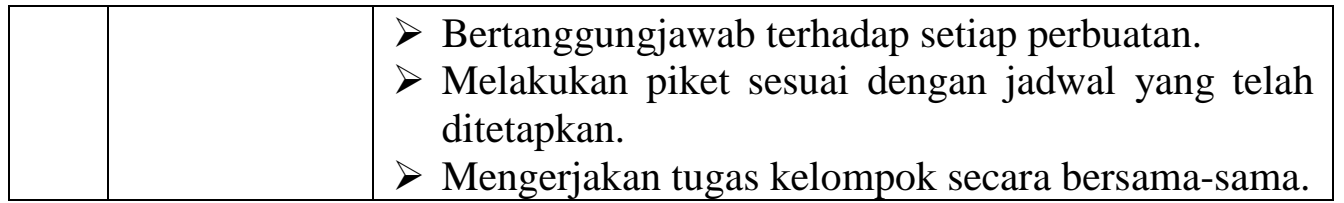

\subsection{Lingkungan Madrasah sebagai Pembentuk Karakter Peserta didik}

Lingkungan sekolah/madrasah adalah segala hal yang memiliki keterikatan baik secara internal atau eksternal yang mendukung dan memiliki tujuan bersama dalam mencapai tujuan pendidikan di sekolah/madrasah tersebut. Salah satu bentuk keterikatan yang menjadi salah satu bentuk standar tercapainya pendidikan adalah penanaman nilai pendidikan karakter pada anak. Nilai pendidikan karakter yang diberikan kepada anak tidak serta merta dibebankan menjadi materi mentah yang sukar diterjemahkan pada anak. Di sinilah peran MI Muhammadiyah 2 Slinga memiliki kegiatan dan aktivitas pembelajaran yang mendukung dalam penguatan nilainilai pendidikan karakter.

Ada 18 nilai yang harus dikembangkan madrasah supaya peserta didik dapat membentuk karakternya menjadi lebih baik. Berikut ini peranan lingkungan Madrasah sebagai pembentuk karakter peserta didik.

\begin{tabular}{|c|c|c|}
\hline No. & Nilai & $\begin{array}{c}\text { Lingkungan Madrasah sebagai pembentuk karakter } \\
\text { peserta didik }\end{array}$ \\
\hline 1. & Religius & $\begin{array}{l}\text { - Sebelum kegiatan pembelajaran dimulai peserta } \\
\text { didik dan guru berdoa bersama. } \\
\text { - Peserta didik membiasakan mengucap salam ketika } \\
\text { memasuki ruang kelas. } \\
\text { - Peserta didik dan guru melaksanakan shalat } \\
\text { berjamaah. } \\
\text { - Peserta didik dan guru merayakan hari besar } \\
\text { keagamaan. }\end{array}$ \\
\hline 2. & Jujur & $\begin{array}{l}\text { - Peserta didik tidak menyontek dalam mengerjakan } \\
\text { soal. } \\
\text { - Peserta didik membayar makanan sesuai dengan } \\
\text { yang dibeli ketika di kantin madrasah. } \\
\text { - Guru bertindak secara transparan mengenai kegiatan } \\
\text { madrasah. }\end{array}$ \\
\hline 3. & Toleransi & $\begin{array}{l}\text { - Ketika diskusi kelompok, peserta didik menghargai } \\
\text { perbedaan pendapat dengan kelompok lain. } \\
\text { - Peserta didik membiasakan diri untuk tidak } \\
\text { mengejek temannya, walaupun ada perbedaan } \\
\text { diantara mereka. } \\
\text { - Tidak adanya perbedaan dalam setiap warga } \\
\text { madrasah. }\end{array}$ \\
\hline 4. & Disiplin & $\begin{array}{l}\text { - Peserta didik membiasakan masuk madrasah secara } \\
\text { tepat waktu. } \\
\text { - Peserta didik mengumpulkan pekerjaan rumah } \\
\text { sesuai dengan waktu yang telah ditentukan. } \\
\text { - Peserta didik mengerti tata tertib madrasah dan } \\
\text { melaksanakannya dengan penuh tanggungjawab. }\end{array}$ \\
\hline
\end{tabular}




\begin{tabular}{|c|c|c|}
\hline 5. & Kerja keras & $\begin{array}{l}\text { - Guru mengadakan perlombaan, sehingga peserta } \\
\text { didik bersemangat untuk dapat memenangi } \\
\text { perlombaan tersebut. } \\
\text { - Guru memberikan motivasi kepada peserta didik } \\
\text { yang akan mengikuti perlombaan sehingga peserta } \\
\text { didik akan belajar lebih keras lagi guna meraih } \\
\text { prestasi yang diidamkan. } \\
\text { - Guru memberikan dorongan secara pasti, mengenai } \\
\text { berkompetisi secara sehat dalam setiap perlombaan. }\end{array}$ \\
\hline 6. & Kreatif & $\begin{array}{l}\text { - Dalam pembelajaran SBK guru memberikan tugas } \\
\text { untuk mengasah kreativitas, misalnya: membuat } \\
\text { asbak dari kertas, membuat mobil-mobilan dari } \\
\text { sandal bekas, membuat bunga dari klaras (daun } \\
\text { pisang yang sudah tua). } \\
\text { - Sesekali guru melakukan kegiatan pembelajaran di } \\
\text { luar madrasah guna mendapatkan ide-ide kreatif dan } \\
\text { segar. }\end{array}$ \\
\hline 7. & Mandiri & $\begin{array}{l}\text { - Guru memberikan tugas secara individu supaya } \\
\text { peserta didik menjadi mandiri dalam mengerjakan } \\
\text { tugasnya, misalnya: peserta didik membuat bingkai } \\
\text { foto dari koran bekas. }\end{array}$ \\
\hline 8. & Demokratis & $\begin{array}{l}\text { - Guru memberikan kebebasan kepada peserta didik } \\
\text { untuk memilih ketua dan pengurus kelas. } \\
\text { - Guru mengarahkan dan mengawasi musyawarah } \\
\text { pembentukan pengurus kelas di madrasah. }\end{array}$ \\
\hline 9. & Rasa ingin tahu & $\begin{array}{l}\text { - Guru memberikan tugas kepada peserta didik untuk } \\
\text { mengamati pertumbuhan tanaman yang ada di } \\
\text { Madrasah sehingga mengasah rasa keingintahuan } \\
\text { peserta didik terhadap setiap perubahan yang ada } \\
\text { disetiap tanaman. }\end{array}$ \\
\hline 10. & $\begin{array}{l}\text { Semangat } \\
\text { kebangsaan }\end{array}$ & $\begin{array}{l}\text { - Secara bersama peserta didik dan guru memajang } \\
\text { gambar tokoh pahlawan bangsa sehingga diharapkan } \\
\text { akan muncul sifat meneladani pahlawan bangsa. } \\
\text { - Secara bersama peserta didik dan guru mengikuti } \\
\text { upacara bendera. }\end{array}$ \\
\hline 11. & Cinta tanah air & $\begin{array}{l}\text { - Di lingkungan Madrasah membiasakan } \\
\text { menggunakan produk-produk Indonesia sebagai } \\
\text { wujud cinta tanah air. } \\
\text { - Dalam kegiatan ekstrakurikuler peserta didik dapat } \\
\text { mengembangkan seni tradisional daerah, misalnya: } \\
\text { kesenian Thek-thek. }\end{array}$ \\
\hline 12. & $\begin{array}{l}\text { Menghargai } \\
\text { prestasi }\end{array}$ & $\begin{array}{l}\text { - Guru dan peserta didik menata kembali Tropi/piala } \\
\text { di madrasah sehingga peserta didik terpacu untuk } \\
\text { berprestasi dan menghargai prestasi orang lain. }\end{array}$ \\
\hline 13. & $\begin{array}{l}\text { Bersahat/ } \\
\text { komunikatif }\end{array}$ & $\begin{array}{l}\text { - Semua warga madrasah berkomunikasi secara baik } \\
\text { dan lancar tanpa membedakan satu sama lain. }\end{array}$ \\
\hline 14. & Cinta damai & - Peserta didik dan guru menciptakan kondisi kelas \\
\hline
\end{tabular}




\begin{tabular}{|c|c|c|}
\hline & & $\begin{array}{l}\text { yang tenteram dalam melaksanakan kegiatan belajar } \\
\text { mengajar di madrasah. } \\
\text { - Semua warga madrasah saling menghargai } \\
\text { perbedaan. }\end{array}$ \\
\hline 15 . & Gemar membaca & $\begin{array}{l}\text { - Dalam pembelajaran Bahasa Indonesia, guru } \\
\text { mengajak peserta didik ke perpustakaan untuk } \\
\text { membaca supaya mendapatkan pengetahuan yang } \\
\text { lebih. }\end{array}$ \\
\hline 16. & $\begin{array}{l}\text { Peduli } \\
\text { lingkungan }\end{array}$ & $\begin{array}{l}\text { - Peserta didik membiasakan untuk piket kelas sebagai } \\
\text { wujud kebersihan kelas. } \\
\text { - Semua warga madrasah ikut memelihara tumbuhan } \\
\text { yang ada di lingkungan madrasah. } \\
\text { - Semua warga madrasah membuang sampah pada } \\
\text { tempatnya sehingga tercipta lingkungan bersih, } \\
\text { sehat, dan nyaman. }\end{array}$ \\
\hline 17. & Peduli sosial & $\begin{array}{l}\text { - Peserta didik dan guru bersama memberikan iuran } \\
\text { guna memberi bantuan kepada mereka yang } \\
\text { mengalami musibah. }\end{array}$ \\
\hline 18. & $\begin{array}{l}\text { Tanggung } \\
\text { Jawab }\end{array}$ & $\begin{array}{l}\text { - Setiap peserta didik bertanggungjawab } \\
\text { melaksanakan tugas piket sesuai dengan jadwal piket } \\
\text { masing-masing. } \\
\text { - Peserta didik mengetahui bahwa setiap perbuatan } \\
\text { pasti akan mendapatkan balasannya, sehingga } \\
\text { peserta didik akan mengerti. }\end{array}$ \\
\hline
\end{tabular}

\subsection{Implementasi Pendidikan Karakter}

Elkind dan Sweet memberikan penjelasan bagaimana pendekatan holistik untuk pendidikan karakter dapat diintegrasikan dan dipadukan dengan baik di dalam lingkup madrasah atau pun sekolah. (Elkind dan Sweet, 2005):

a. Perpaduan antar siswa guru dan masyarakat sebaiknya memiliki hubungan yang diatur di sekolah.

b. Keterlibatan antar siswa dan guru serta madrasah menjadi bentuk keterikatan dan kepedulian.

c. Pendidikan emosi dan sosial memiliki kesetaraan pada pendidikan akademik.

d. Pengembangan dan perpaduan antar siswa menjadi prioritas daripada kompetisi.

Sementara itu, peran lembaga pendidikan atau madrasah dalam implementasi pendidikan karakter mencakup:

a. Mengumpulkan guru, orangtua dan peserta didik bersama-sama mengidentifikasi dan mendefinisikan unsur-unsur karakter yang mereka ingin tekankan.

b. Memberikan pelatihan bagi guru tentang bagaimana mengintegrasikan pendidikan karakter ke dalam kehidupan dan budaya madrasah.

c. Menjalin kerjasama dengan orangtua dan masyarakat agar peserta didik dapat mendengar bahwa perilaku karakter itu penting untuk keberhasilan di madrasah dan di kehidupannya.

d. Memberikan kesempatan kepada kepala madrasah, guru, dan orangtua dan masyarakat untuk menjadi model perilaku sosial dan moral. 


\subsection{PenerapanPendidikan Karakter di Madrasah}

Proses pembentukan karakter akan jauh dari kesan dan praktik doktrinasi yang menekan, justru sebaliknya, peserta didik akan mencintai berbuat baik karena dorongan internal dari dalam dirinya sendiri.

Adapun cara agar sukses menerapkan pendidikan berbasis karakter di madrasah antara lain:

a. Memiliki nilai-nilai yang dianut dan disampaikan kepada seluruh stake holder madrasah melalui berbagai media, antara lain, buku panduan untuk orang tua (dan peserta didik), news untuk orangtua, pelatihan.

b. Staf pengajar dan administrasi termasuk tenaga kebersihan dan keamanan mendiskusikan nilai-nilai yang dianut, nilai-nilai ini merupakan penjabaran dari nilai-nilai yang diyakini madrasah.

c. Peserta didik dan guru mengembangkan nilai-nilai yang dianut di kelas masing-masing.

d. Memberikan dilema-dilema dalam mengajarkan suatu nilai, misalnya tentang kejujuran.

e. Pembiasaan penerapan nilai di setiap kesempatan.

f. Mendiskusikan masalah yang terjadi apabila ada pelanggaran.

g. Mendiskusikan masalah dengan orang tua apabila masalah dengan anak adalah masalah besar atau masalahnya tidak selesai.

Dari semua komponen yang ada di madrasah, yang paling berperan mensukseskan program pendidikan berbasis karakter di madrasah adalah guru.

3.5.Perilaku peserta didik di Lingkungan Madrasah yang menggambarkan Pendidikan Karakter

a. Pesertadidik memiliki sikap religius di lingkungan Madrasah.

b. Ketika jajan di Madrasah, peserta didik membayarnya dengan jujur.

c. Peserta didik memiliki rasa toleransi ketika melakukan pengamatan bersama.

d. Peserta didik masuk kelas secara disiplin.

e. Peserta didik bekerja keras dalam menyelesaikan tugas di madrasah.

f. Dalam membuat anyaman bambu atau ketrampilan lainnya, peserta didik terlihat kreatif.

g. Peserta didik mandiri dalam menyelesaikan soal/tugas di Madrasah.

h. Peserta didik melakukan pemilihan ketua kelas secara demokratis, melalui pemungutan suara pemilihan pengurus kelas.

i. Peserta didik melakukan pengamatan guna memecahkan rasa ingin tahu.

j. Peserta didik dan guru mengikuti upacara bendera bersama sebagai wujud semangat kebangsaan.

k. Peserta didik belajar seni tradisional kentongan sebagai wujud cinta tanah air.

1. Peserta didik saling menghargai prestasi orang lain dengan mengucapkan selamat kepada teman yang meraih prestasi.

m. Peserta didik bersahabat membersihkan lingkungan secara bersama-sama.

n. Dalam pembelajaran peserta didik menjaga ketenangan supaya tidak mengganggu ketenangan kelas.

o. Peserta didik gemar membaca supaya pengetahuan mereka semakin bertambah dengan aktif datang ke Perpustakaan Madrasah.

p. Secara bersama, peserta didik membuang sampah pada tempatnya supaya lingkungan menjadi bersih dan jauh dari penyakit.

q. Peserta didik peduli social kepada orang yang membutuhkan dengan berperan serta dalam penggalangan dana untuk membantu korban bencana alam.

r. Secara bersama membersihkan lingkungan, mereka bertanggungjawab dalam melaksanakan tugas piket. 


\section{KESIMPULAN}

Pendidikan Nasional bertujuan membentuk manusia Indonesia sebagai pribadi dan sebagai warga masyarakat yang mampu membangun dirinya sendiri dan ikut membangun bangsanya. Guru merupakan orang yang memiliki profesi mengajari orang lain. Mengajari orang lain biasanya terdapat di madrasah. Seiring berjalannya waktu di masa sekarang ini tugas guru semakin bertambah berat, karena orangtua siswa telah mempercayakan semua pembelajaran di madrasah. Hal-hal yang dapat dilakukan oleh guru untuk menanamkan pendidikan karakter antara lain : adanya optimalisasi peran guru dalam pembelajaran, adanya integrasi materi pendidikan karakter kedalam mata pelajaran, adanya optimalisasi kegiatan pembiasaan diri yang berwawasan pengembangan budi pekerti dan akhlak mulia, menciptakan lingkungan madrasah yang kondusif untuk tumbuh dan berkembangnya karakter peserta didik, menjalin kerjasama dengan orangtua peserta didik dan masyarakat lingkungan sekitar, dan hendaknya guru bisa menjadi teladan bagi peserta didik.

\section{DAFTAR PUSTAKA}

[1] Anton,M Mulyono. 2007. Kamus Besar Bahasa Indonesia. Jakarta: Balai Pustaka.

[2] Zaenul, Agus. 2012. Pendidikan Karakter Berbasis Nilai dan Etika di Madrasah. Jogjakarta: Ar-ruzz Media.

[3] Rahmat, Imadadun. 2014. Guru Berkarakter untuk Implementasi Pendidikan Karakter. Yogyakarta: Gava Media.

[4] Adisusilo, Sutario. 2012. Pembelajaran Nilai Karakter. Jakarta: PT. Raja Grafindo Persada.

[5] Suranto. 2010. Komunikasi Sosial Budaya. Yogyakarta: Graha Ilmu

[6] Ningsih, Tutuk. (2015). Implemetasi pendidikan Karakter. Purwokerto: STAIN Press

[7] Depdiknas. (2006). Permendiknas No 22 Tahun 2006 Tentang Standar Isi. Jakarta: Depdiknas

[8] Kemendiknas. (2010). Desain Induk Pendidikan Karakter.Jakarta: Kemendiknas.

[9] Undang-Undang Republik Indonesia Nomor 20 Tahun 2003 tentang Sistim Pendidikan Nasional

[10] Probowati, Yusti, dkk. 2011. Pendidikan Karakter Perspektif Guru dan Psikolog. Malang : Penerbit Selaras

[11] Mustoip, Sofyan, dkk. 2018. Implementasi Pendidikan Karakter, Surabaya : Jagad Publishing

[12] Rasimin, Multikulturalisme (Teori dan Aplikasi dalam Pendidikan IPS), Yogyakarta, Kreasi Total Media

13] Riana Monalisa Tamara, Gea, Jurnal Pendidikan Geografi, Volume 16, Nomor 1, April 2016, hlm 44-55.

[14] Jito Subianto ,Peran Keluarga, Sekolah, Dan Masyarakat Dalam Pembentukan Karakter Berkualitas Edukasia: Jurnal Penelitian Pendidikan Islam

[15] https://media.neliti.com/media/publications/285795-pembentukan-karakter-anak-melaluilembag-cfae5928.pdf

[16] Kaimudin, Pembentukan Karakter Anak Melalui Lembaga Pendidikan Informal : Jurnal AlMaiyyah, Volume 11 No. 1 Januari-Juni 2018

[17] Johansyah, Pendidikan Karakter Dalam Islam; Kajian dari Aspek Metodologis : Jurnal Ilmiah Islam Futura, Volume XI, No. 1, Agustus 2011 